SECTION 8. Architecture and construction

\author{
Nadiya Rostyslavivna Vildanova \\ Master of construction, Doctoral student, \\ Odessa State Academy of Building and Architecture, Odessa, Ukraine, \\ e-mail: adhimaratma@gmail.com
}

\title{
THE BILINEAR SHEARING STRESS-STRAIN CURVE FOR CONCRETE
}

\begin{abstract}
The simplified bilinear shearing stress-strain chart of the complete stressstrain curve for concrete in shear and pure torsion has been elaborated on the basis of the experimental research and offered for the reinforced concrete elements' stiffness' calculation.

Key words: torsional stiffness, bilinear stress-strain curve for concrete, pure torsion, the secant shearing modulus of concrete.
\end{abstract}

The bending stiffness' studies and mechanical strength characteristics' investigation of RCE under compression-tension are being paid much attention by modern researchers while comparing with the analysis of the torsional effect on the reinforced concrete elements' work. However it should be studied not less because of structures' constant necessity to resist the effect of not only bending and compressing forces but of the torsional ones (for example, in any asymmetrical loading of the spatial structures' elements like bridge superstructures, overlap constructions, as the influence of the forces' redistribution on the side beams causes torsion of the main girder; not to mention spiral staircase and boundary elements of shells and domes etc.). In the issue the building standards and the software packages account the bending stiffness' changing at all the stages of reinforced concrete elements' work, in contrast to the torsional stiffness' reduction owing to the concrete secant shearing modulus' decreasing. And the educational process also avoid shearing stress-strain curve's studying.

The shearing stress-strain curve [21] should be used as the generalized characteristic of the concrete mechanical properties, similar to the compression stress-strain curve [10]. However modern building standards - neither post-Soviet, nor Australian, American, European and others - do not provide design of reinforced concrete structures considering secant shear modulus of concrete $[1,7-9,12-13,16-17,19]$, while in compression-tension using secant Young's modulus of concrete is prevailing. It can be explained by the lack of the experimental data of the complete shearing stress-strain curve for concrete $[4,6,10-11,14-15$, 18, 21-22]. The principle of shear and compression stress-strain curve's obtaining for the concrete is common. The difficulty is in the experimental definition of the descending branch's parametric points using traditional experimental settings because of the sudden element's destruction as a result of the ultimate potential deformation energy immediate realization to the impact energy. The essence of the new method of obtaining the shearing stress-strain curve for concrete is in the use of traverse for a supervised efforts' transfer on a concrete model $[3,5]$. That's why the experimental research has been conducted, where parametrical points of the curve's descending branch have been defined $[2-3,5,20]$. Complete shearing stress-strain curve has been already explained [2-3, 5], and after the experimental confirmation it is possible to introduce it into design practice.

To simplify the nonlinear shearing stress-strain curve [21] for the engineering estimations the parameters of the bilinear shearing stress-strain chart (fig.1) have been defined by analogy with the compressive-tensile stress-strain diagram [9].

On the fig. 1 is noted: 1 - bilinear characteristic stress-strain curve $\tau-\gamma$ for concrete in shear (where the secant shear modulus is defined as the constant, or initial one multiplied by the coefficient of the secant shear modulus' change $G_{c}=G_{c}^{0} \vartheta_{c}=E_{c}^{0} \vartheta_{c} /\left[2\left(1+\mu_{c}\right)\right]$, according to 
[21]); 2 -shearing stress-strain chart for concrete confirmed by the experiments in pure torsion [5]; 3 - bilinear calculation stress-strain chart for concrete under shear $\tau-\gamma$.

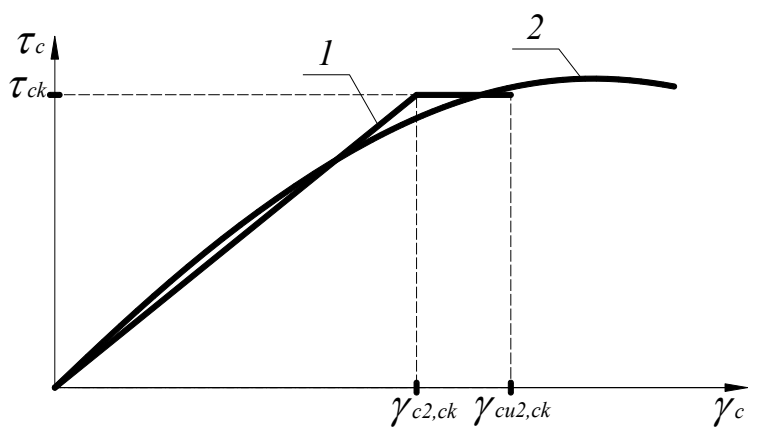

a)

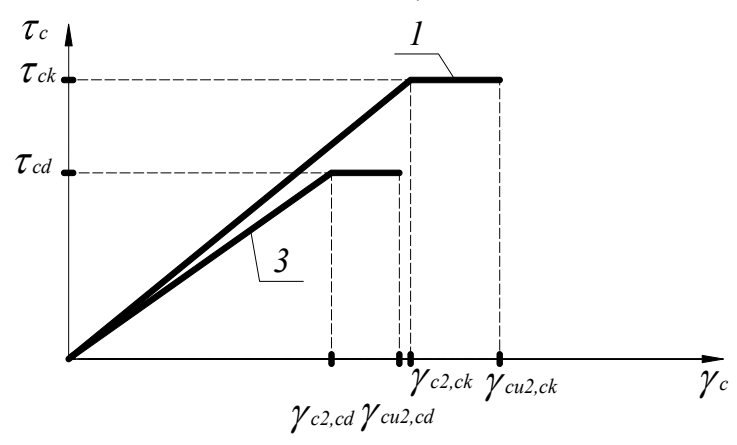

b)

Figure 1 - a) Calculation and experimental $\tau-\gamma$ dependences;

b) Bilinear stress-strain chart for concrete under shear

Equivalent critic values of stresses and deformations for the shearing stress-strain curve are prescribed according to the theoretical chart [21] and confirmed experimentally [2$3,5]$. The shearing stresses $\tau_{c}$ of the bilinear shear stress-strain curve should be calculated depending on the relative angular deformations $\gamma_{c}$ as

$$
\begin{aligned}
& \tau_{c}=G_{c} \gamma_{c} \text { when } 0 \leq \gamma_{c} \leq \gamma_{c 2} ; \\
& \tau_{c}=\bar{\tau}_{c} \text { when } \gamma_{c 2} \leq \gamma_{c} \leq \gamma_{c u},
\end{aligned}
$$

where ultimate shearing stress is equal to the concrete shearing strength, which depends on the values of compressive $f_{c k}$ and tensile $f_{c t k}$ concrete resistance $\tau_{c}=\bar{\tau}_{c}=f_{c, s h}=0.7 \sqrt{f_{c k} f_{c t k}}$ according to [21].

Accepted notation conventions for the strength and deformability of concrete in shear (similarly to the concrete characteristics in compression according to [8-9]) are given below. Shearing stresses: $\tau_{c m}=\tau_{c k} /\left(1-1.64 V_{c}\right)$ is the average value of the concrete shearing strength, where the constant of variation is equal to $13.5 \% ; \tau_{c k}$ is the characteristic value of the concrete shearing strength; $\tau_{c d}=\tau_{c k} / \gamma_{c t}$ is the calculation value of the concrete shearing strength, where the safety factor is taken as for tension, not compression, as the result of the concrete elements' destruction by reason of the tensile stresses' effect $[3,5]: \gamma_{c t}=1.5$ when $\tau_{c d, 0.05} ; \gamma_{c t}=1.3$ when $\tau_{c d, 0.95}$. Stiffness' characteristics: $G_{c m}$ is the average value of the initial rigidity modulus of concrete; $G_{c k}$ is the characteristic value of the initial rigidity modulus of concrete; $G_{c d}$ is the calculation value of the initial rigidity modulus of concrete. Angular deformations: $\gamma_{c}$ is the value of the relative angular deformations for concrete in shear; $\gamma_{c 2}$ is the value of the relative angular deformations for concrete in shear correspondingly to the ultimate shearing stresses $\tau_{c k} ; \gamma_{c u}$ is the value of relative ultimate angular deformations of concrete under shear; angular deformations $\gamma_{c 2, c k}=\tau_{c k} / G_{c k}$; 
$\gamma_{c 2, c d}=\tau_{c d} / G_{c d} ; \gamma_{c u 2, c k}=k_{t} \times \gamma_{c 2, c k} ; \quad \gamma_{c u 2, c d}=k_{t} \times \gamma_{c 2, c d}$, where values of the relative ultimate angular deformations for concrete in shear are accepted after the analysis of the experimental data, according to which the shearing angle increases by $k_{t}=24 \%$ as compared to the peak point of the curve accordingly to the experiment [5]. When introducing the bilinear chart to the standards on the basis of the experiments' extension one could vary the very value of the $k_{t}$ coefficient.

For example, the stress-strain curve for the fine-grained concrete C16/20 in shear has been built (fig.2).

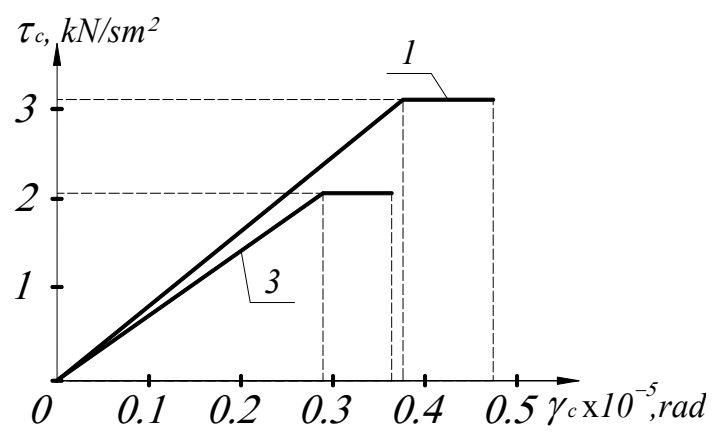

Figure 2 - Bilinear shearing stress-strain chart of the fine-grained concrete $\mathrm{C16} / 20$

For the concrete $\mathrm{C} 16 / 20$ according to the experimental data theoretical value of the ultimate shearing stress $\bar{\tau}_{c}=0.3091 \mathrm{kN} / \mathrm{sm}^{2}$, average actual experimental value of the ultimate shearing stress $\bar{\tau}_{c}=0.3163 \mathrm{kN} / \mathrm{sm}^{2}$, the error is $2.27 \%$. The elasticity modulus $E_{c}^{0}$ of heavyweight concrete is $2700 \mathrm{kN} / \mathrm{sm}^{2}$, of fine-grained one is $2200 \mathrm{kN} / \mathrm{sm}^{2}$. On the fig. 2 the value of the shearing stresses and angular deformations according to the computation by the above mentioned formulas are:

$$
\begin{aligned}
& \bar{\tau}_{c k}=3.10 \mathrm{MPa}, \tau_{c d}=2.07 \mathrm{MPa}, \tau_{c m}=3.98 \mathrm{MPa} ; \\
& \gamma_{c 2, c k}=\tau_{c k} / G_{c k}=0.389, \gamma_{c u 2, c k}=0.24 \times \gamma_{c 2, c k}=0.482 \text {, } \\
& \gamma_{c 2, c d}=\tau_{c d} / G_{c d}=0.298, \gamma_{c u 2, c d}=0.24 \times \gamma_{c 2, c d}=0.370 \text {. }
\end{aligned}
$$

The safety factor's values for the limit state of the $1^{\text {st }}$ and the $2^{\text {nd }}$ principal criteria for concrete (the ultimate limit state (ULS) and the serviceability limit state (SLS), according to the limit state theory) are taken according to the tab.2.1 of the Standard [9].

So, application of the bilinear concrete shearing stress-strain chart while using secant shearing modulus of concrete in order to consider the torsional stiffness' reduction in calculations essentially simplifies estimations comparatively with the usage of the concrete secant shear modulus according to the theoretical stress-strain curve.

\section{References:}

1. ACI 445R-99 Recent Approaches to Shear Design of Structural Concrete. Published: 1999 (Reapproved 2009) Farmington Hills: ACI, 2009. - 55p.

2. ACI 318M-08 Building Code Requirements for Structural Concrete (ACI 318M-08) and Commentary. Farmington Hills: ACI, 2007. - 473p.

3. Azizov T.N., Vildanova N.R. Influence of the Shear Modulus of Concrete on the Structures' Spatial Work. Proceedings: 3d International Conference on Science and Technology 21-22 October 2013, London: Berforts Information Press Ltd, UK, 2013. pp.97-106.

4. Azizov T., Vildanova N. Theoretical and Experimental Research of the Complete Shearing Stress-Strain Diagram. Geodesy, Architecture \& Construction: Proceedings of the 5th 
International Conference of Young Scientists GAC-2013. - Lviv: Lviv Polytechnic Publishing House, 2013. - pp.64-65.

5. Azizov T.N. Teorija prostranstvennoj raboty perekrytij [Theory of the overlappings' spatial work]. Kiev: Naukovij svit Publ., 2001. - 276p.

6. Azizov T.N., Vildanova N.R. Experimental investigation of the nonlinear shear diagram of concrete. - Collection of scientific works of Odessa State Academy of Building and Architecture. Issue 46 - Odessa: OSABA, 2012. - P.3-8.

7. Best C.H. Significance of Test and Properties of Concrete and Concrete Making Materials. ASTM International, 1978. - 882p.

8. BS EN 1992-1-1:2004 Eurocode 2: Design of concrete structures. General rules and rules for buildings. London, 2004. $-230 \mathrm{p}$.

9. DBN V.2.6-98:2009. Betonni ta zalizobetonni konstruktsiyi. Osnovni polozhennya. [Concrete and Reinforced Concrete Structures. Substantive Provisions. Since 1.07.2011] K.: Minregionbud of Ukraine, 2011. - 71p.

10. Karpenko N.I. Teorija deformirovanija zhelezobetona s treshhinami. [The theory of reinforced concrete with cracks' deformation]. M.: Strojizdat, 1976. - 208p.

11. Kemp E.L. Torsion in Reinforced Concrete. A report on a Research Project Sponsored by The University Research Board // E.L.Kemp, M.A.Sozen, C.P.Siess. - Urbana, Illinois: University of Illinois, 1961. - 128p.

12. Chyuan L.D. Torsion in Reinforced Concrete Structures Design Requirements and Procedures in BS 8110 and Eurocode 2. Malaysia: Universiti Teknologi Malaysia. Faculty of Civil Engineering, 2007. - 140p.

13. Code of Practice for Structural Use of Concrete/Buildings Department. Hong Kong: The Government of the Hong Kong Special Administrative Region, 2013. - 207p.

14. Cowan H.J., Armstrong S. Experiments on the Strength of Remforced and Prestressed Concrete Beams and of Concrete-Encased Steel Joints in Combined Bending and Torsion. - Magazine of Concrete Research,Vol.6,No.19. - U.K.: London,1955. - pp. 3-20.

15. Cowan H.J. Kruchenie v obychnom i predvaritel'no napriazhennom zhelezobetone. [Torsion in the ordinary and prestressed reinforced concrete].M.: Strojizdat. $-104 \mathrm{p}$.

16. CSA A23.3-04 (R2010) Design of Concrete Structures. Canadian Standards Association, Ontario, 2004. - 214p.

17. GrubeH., Kerkhoff B. Die neuen deutschen Betonnormen DIN EN 206-1 und DIN 1045-2 als Grundlage für die Planung dauerhafter Bauwerke/The new German concrete standards DIN EN 206-1 and DIN EN 1045-2 as basis for the design of durable constructions/ Betontechnische_Berichte 019-028. Betonnormen. Deutshland, 2003. Ss. 19-28.

18. Hsu T.T.C. Torsion of Structural Concrete A Summary on Pure Torsion // Symposium on Tor sion, SP №18, American Concrete Institute, 1968.- SP-18, 165-178.

19. PN-B-03264:2002 Konstrukcje betonowe, żelbetowe i sprężone. Obliczenia Statyczne I Projektowanie. Polski Komitet Normalizacyjny, 2002. - 142s.

20. Vildanova N.R. The Concrete String Element of the Circular and Annular Section's Deflection Mode under the Action of Torsion Taking into Account the Shear Modulus/ Research Bulletin SWorld: Modern scientific research and their practical application. VolJ21304// Odessa: Kupriyenko SV, 2013. - pp.57-64.

21. Yaremenko O.F., Shkola Yu.O. Nesucha zdatnist' ta deformatyvnist' zalizobetonnykh sterzhnevykh elementiv v skladnomu napruzhenomu stani [The reinforced concrete strain elements' bearing capacity and deformability in a compound stress]. Odessa: ODABA, 2010. - 136p.

22. Zia P. What do We Know about Torsion in Concrete Members? / P. Zia // SD Journal ASCE. - 1970. - N 6. - P.1185. 